\title{
STATE SUPPORT PROVIDED TO CINEMA FILMS IN TURKISH LEGAL SYSTEM
}

\author{
Sevil Yildiz \\ Assoc. Prof. Dr., Selcuk University, Communication Faculty, TURKEY \\ syildiz@selcuk.edu.tr
}

\begin{abstract}
Cinema politics is based on the combination of the different features such as interaction with society international circulation, industry specific settlement, and relationship with technology, industry, art, and mass media. The policies created for the cinema field are under the influence of economic and cultural values. Interventionism, protectionism and support should be assessed in this context in the field of cinema. From the beginning until 1987, Turkish cinema has been developed and developed with its own internal dynamics without being supported by the state. The Turkish cinema has developed its own production style without rely on the non-sector capital and with the domestic audience in the domestic market without receiving state support. State support to the cinema which has been recently restructured has been provided by the Law No. 5224 on the Evaluation, Classification and Supporting of Cinema Films. It is the first time that Turkish cinema has a Law. It has been accepted in the Assembly that it is a sector in which cinema is supposed to be supported and promoted.

The purpose of this study to assert the film support systems briefly and particularly present a general evaluation of the consequences the Regulations for Supporting as well as Supervising and Classifying the Cinema Films on the basis of the Law No. 5224 pertaining to the Evaluation, Classification and Support of the Cinema Films with respect to the Turkish cinema in the frame of cinema policies.
\end{abstract}

Keywords: Cinema films, supporting, state support, Law No. 5224

\section{INTRODUCTION}

Turkish cinema is a sector, which managed to reach 90s without government assistance and that knows how to survive with the revenues, obtained from national cinemagoers, and thanks to its internal dynamics without branching out. Within this period, the state hadn't made any significant contribution to the cinema no other than tax reduction of 1948; furthermore, it took a quite toll on the cinema with the rule of censorship in 1939. The fact that Turkish Cinema failed to be institutionalized and industrialized frequently pit the moviemakers against state, meetings were held in order to seek solutions, councils were organized, however no 
favorable results could be obtained. In a period where Turkish cinema goes through a crisis and it is restructured, the thought that art of cinema must be subsidized so that it could develop gained importance; and Law no. 5224 on Evaluation, Classification and Promotion of Motion Pictures by Ministry of Culture and Tourism entered into force in 2014. Following two regulations; Regulation on Promotion of Motion Pictures and Regulation on Supervision and Classification of Motion Pictures were issued based on the provisions of this Law.

Law no. 5224 concerning the Evaluation, Classification and Promotion of Motion Pictures, which regulates the evaluation, classification of, and how the state will subsidize motion pictures in Turkish Legal system, was acknowledged by the Assembly in 2004. Since therefore, Turkish cinema had had a regulation for the first time. It was envisaged in Law no. 5224, which is discussed since it was enforced, (Kıvanç, 2004. p.1),to organize following Advisory Board, Support Board, Evaluation Board and a Classification Board. As regards the first reactions in the press, it was pointed out that the legislation would bring the cinema sector completely under the control of the government and the Ministry of Culture and Tourism (Doğan 2004. p.1); it would place the movie-makers in a challenging circumstance to hold the director along with the producer responsible for repayment as well as Film Production Support Agreement, which is requested against the subsidy and that it would create pressure on the movie-makers to claim the subsidy back if it is decided on the use of markers and symbols as a result of evaluation and classification of subsidized production projects (Hızlan, 2005; p.1). Several criticized sections of the Law were rearranged thereby making amendments as part of Law on Intellectual and Artistic Works, promulgated in Official Gazette no. 26402, dated January 13, 2007, Law on Travel Agencies and Association of Travel Agencies and the Law on Promotion of Tourism as well as some Law on Amending Some Other Legislations. It was stated that some issues regarding supervision and classification will be settled through the regulation to be issued thereof (Erkılıç, 2008, p. 77).

\section{EVALUATION AND CLASSIFICATION BOARD}

Article 5 of Regulation on Supervision and Classification of Motion Pictures identifies how to carry out Evaluation and Classification. Following provision is included in the Regulation "Assessment and classification of motion pictures are carried out by the Evaluation and Classification Board, established within the Ministry." Members of the Board consists of nine members; one member from the Ministry of Culture and Tourism, Ministry of Internal Affairs and Ministry of National Education, three members to be selected by the Ministry among the experts to be offered by relevant professional associations and a sociologist, a psychologist and a child development specialist with doctor of philosophy to be determined by the Ministry. The Board gathers with the participation of minimum six members and takes the decisions with the votes five members in the same direction. Determining the evaluation and classification issues, Article 11 of the Regulation is as follows: "Boards, established within the Ministry evaluate the motion pictures in accordance with public order, protecting mental and physical health of the minors and the young, compliance with human dignity and other policies, envisaged in the Constitution in consideration of forms of display and transmission and it is not allowed to release or present the movies, which are against these principles for commercial circulation. Furthermore the Regulation also authorizes the Board "to send movies containing violence, pornography as well as impressions and images incompatible with human dignity directly to the Evaluation and Classification Board for reassessment in order to protect human dignity, public order, public morality, mental and physical health of the children and the young. "This approach was interpreted to be a control mechanism rather than evaluation and classification (Özonur, 2010, p. 14).

Pursuant to Article 9 of the Regulation, evaluation and classification of the movies, which are imported or produced in Turkey is made by the Board so as to constitute the basis for recording and registration before putting on commercial circulation and display. Movies, which are considered to be suitable following the assessment and classification, are not allowed to be put on commercial circulation and display. Movies, which are considered to be suitable following the evaluation and classification and that have made the required corrections are allowed for circulation after they are recorded and registered by applying banderoles on the media recording such movies. If Law no. 5224 requires that the movies bear the markers or symbols to show the result of evaluation and classification, it is compulsory to show such markers and symbols on any display and promotion area as well as the recordable media. The same markers and symbols are also included in the recording and registration document, certificate for the use of financial rights. Ensuring the insertion of symbols to warn the audience against the acts of violence/fear, sexuality and negative samples and classifying the movies based on proper age groups pursuant to Regulation on Principles and Procedures Regarding the Evaluation and Classification of Motion Pictures, the Board classifies the audience in accordance with the ages of 7,13,18 and over or the whole audience. The Ministry may, at any time, control if warning markers or symbols to show the content are complied with and whether or not sales, distribution and display is made in compliance with the age group, identified with these markers. 


\section{ADVISORY BOARD}

Pursuant to applicable regulation, it was adopted to establish an Advisory Board within the Ministry of culture and Tourism in order to explore the major approaches, sectoral trends and tendencies regarding the art of cinema and establish an efficient communication. Besides, this Board consists of representatives from relevant professional associations and sectoral non-governmental organizations one for each, five instructors to be offered by the universities and determined by the Ministry as well as three well-known persons in cinema industry, to be determined by the Ministry. In order to explore the major approaches, sectoral trends and tendencies regarding the art of cinema and establish an efficient communication, the Advisory Board takes advisory decisions regarding the following issues to;

-create a modern and efficient cultural communication media so that individuals and the society could make use of the products of art of cinema productively and benefit from the opportunities offered by the art of cinema,

- develop and strengthen the cinema industry in the fields of training, investment, enterprise, production, distribution and display,

-support the employees of cinema industry and resolve their economic and social problems.

\section{SUPPORT BOARD}

Pursuant to Law, Support Board of Ministry of Culture and Tourism is authorized for supporting the projects and the applications to this Board are evaluated by the aforementioned Board. According to the Regulation, Support Board consists of members, one for each, selected among their members by professional associations of relevant area and the representative of the Ministry as well as three members to be determined by the Ministry among the experts to come to the fore in the fields regarding cinema. The number of board members shall not exceed 15. Pursuant to Article 6 of Law no. 5224, Cinema Support Board consists of representatives of professional associations such as SESAM (Professional Association of Turkish Cinematographic Works), SETEM (Professional Association of the Owners of Television and Cinematographic Works), SINEBIR (Professional Association of the Owners of Cinematographic Works), BSB (Professional Association of the Owners of Documentary Cinematographic Works), TESIYAP (Professional Association of Producers of Television and Cinematographic Works), FIYAP (Professional Association of Movie Makers) as well as three members to be determined by the Ministry among the experts in the fields related to cinema and the representative of the Ministry. Support Board thus restored as a structure mainly consisting of the representatives of cinema sector.

Resolutions and operation procedures of the Support Board are specified in Article 10 of the Regulation. In consideration of advisory decisions by the Advisory Board, Support Board takes resolutions regarding for which types of promotion and in which rates and limits the funds, allocated by the Ministry for supporting motion pictures, would be used and informs Ministry of Culture and Tourism and the related parties about such decisions after they are approved by the Ministry. Motion pictures, applications of which are deemed suitable by the Support Board, benefit from support areas in accordance with the following provision as regards the "Promotion of the projects concerning the fields of production, scripting, archiving, documentation, technical infrastructure, training, research, development, display, distribution, marketing and presentation in cinema sector" pursuant to sub-clause $g$ of Article 3 of Law no. 5422. It is stated in the Assessment Criteria in article14 of the Regulation that Support Board evaluates the applications in terms of content and budged and considers following criteria while making such assessment such as bearing qualitative value and originality in terms of culture, art and aesthetics; contribution to promotion of culture and cultural values, protection of public order, public morality as well as mental health of the minors and the young, compliance with human dignity and other principles, envisaged in the Constitution; factuality of budget, financial plan and feasibility of implementation schedule; national and international achievements as well as previous studies, if any; furthermore the field-experience of producers, directors and art team, taking part in production in the applications for production support, national and international circulation potential of the project, besides providing opportunity to raise new artists (Ulusoy, 2003, p. 209).

Ministry aid consists of three main parts as the project support, production support and post-production support. Project support is provided directly and without repayment in order to support the stages before the production such as research, development, writing scenario and dialogues, translation, design etc. Production support is provided directly or indirectly with repayment in order to support all production stages from preparation phase of the movies before production to the stage in which display could be made. Production support is only provided with repayment for all production phases from preparation phase of the motion pictures before production to the stage in which display could be made. Post-Production support is 
provided directly or indirectly with or without repayment in order to transmit motion pictures to the audience as well as supporting the promotion, distribution and display phases. Pursuant to the legislation, production aids are provided only with repayment. For fiction movies, this support is based on the condition that the director and producer made an application, the cinema version of the production would be made and that cinema hall display of the movie would be made in advance. However; these conditions do not apply for documentary, animation and short films ( Doğan. D.Ç, 2010, p. 79)

The most controversial and significant articled in support system seems to be Article 24, which specifies the sanctions. As per this article, following provision may be considered as a sanction for the movie-makers in which it is stated that provided support for these projects would be taken back if it is made compulsory to use cautionary markers and symbols following the evaluation and classification in the movies, which are created after realization of subsidized production projects.

As per Article 8 of Law no. 5224 on Evaluation, Classification and Promotion of Motion Pictures and Article 17 of Regulation on the Promotion of Motion Pictures, Support Board determined some international festivals, which may be exempted from repayment in production support with respect to repayment of the support provided for fiction films. As it stands, legislations and regulations direct the movie-makers to make films, which will either do well at the box office or receive awards in the festivals determined thereof. This results in an outcome contrary to the spirit of support policies. If support policies are developed in terms of national culture and identity, then why are the movie-makers left in position to make a choice between these two attitudes? If such an attitude is an incentive for the movie-makers to expand overseas, then other regulation, in which expanding overseas would be supported are required.

\section{SUPPORT DISCUSSIONS AND PERFORMED REGULATIONS}

Discussions regarding the field of support have centered upon the type of repayment, agreement form and the obligation to release within the same year. Pursuant to the Law, supports, which are provided as production support with repayment, are paid by the producer from the revenues obtained after bearing the costs of production in accordance with the principles and procedures to be determined by the Ministry. In the event that the movie fails to obtain revenue in the amount to bear the expenses of production, supports with repayment are deemed to be non-repayment aids (Erkılıç, 2008, p. 78). However; the director of the movies, repayment of which were failed to be completed, will not be able to make use of the supports, specified in this Law for three years and the producer will never benefit from the same other than the movies, which are invited to, or obtained an award in the international festivals, specified by the Support Board. In the event that the amount, which is considered to be non-repayment along with legal rate of interest, is paid back to the Ministry, the producer may apply again in order to make use of the support. Besides, the obligation not the use the granted subsidy within the same year may not be suitable for sectoral operation of cinema. Reclaiming the support, which is not, used within the year pursuant to the agreement pit the movie-makers against the Ministry (Özonur, 2010, p.8). Criticized by the Cinema sector and Advisory Board, this article was amended in accordance with Law on Intellectual and Artistic Works, promulgated in Official Gazette no. 26402, dated January 13, 2007, Law on Travel Agencies and Association of Travel Agencies and the Law on Promotion of Tourism as well as some Law on Amending Some Other Legislations. To be included after the first sentence of sixth sub-clause of Article 8 of Law no. 5224 on Evaluation, Classification and Promotion of Motion Pictures, dated 14/7/2004, following sentences are added "Repayment in the rate of support provided for total project costs and in an amount not to exceed this support is made from the remaining net amount after the expenses made for such production are deducted from the total revenue, obtained from the production by the end of the calendar year following the year in which the production is released. In the event that the production is not released or it is failed to determine the date, it is considered to have been released at the latest by the end of the calendar year following the year in which the support is provided," following expression, included in the third article of the same sub-clause: "the director...for three years and the producer will never..." was amended as "the producer will...for three years" and the following expression, included in the first sentence of sub-clause eight: "...30\% of the total costs for production and post-production expenses, for project costs" was removed from the text of the article. Articles, which are not suitable for the operation of cinema industry that penalizes the movie-makers, are removed thanks to this regulation.

\section{CONCLUSION}

Cinema policies must be in an intervening structure to contain support so that national cinemas could survive (Aas, 2001, p. 102). Turkish cinema obtained a regulation for the first time with Law no. 5224. Thanks to this legislation, it was acknowledged that cinema is a sector, required to be supported and promoted. A support system was developed in compliance with contemporary cinema policies in the world. The task to evaluate 
and classify cinematographic works was assigned to the sectors and the experts thereof. And the fund, created by cinema sector through entertainment taxes was transferred to the management of the sector. While documentary, short film and animation projects are subsidized free of charge, it is a remarkable development for Turkish cinema to include script development support.

In addition to these, there are some areas in which legal regulation is required in terms of support policies. Regulations must be made so that cinema can also benefit from the law on sponsorship. Regulations on tax, investment and customs must me constituted again. It is essential to strengthen the support fund by transferring shares into the field of cinema from television revenues. Turkish film distributors abroad must be promoted, included under support, and an agency must be established for this. It is required to make legislative regulations in compliance with technological changes, emerging as part of digital cinema concept. It is essential to help the sector prepare for all this process in terms of infrastructure.

Thanks to the cinema policy framed by Turkish cinema with promotion, evaluation and classification, a production increase is observed in the number of films. Creating a vision for the future, Turkish cinema must redesign the cinema policy in order to be able to expand in international market.

\section{REFERENCE LIST}

Aas, N. (2001). Challenges in European Cinema and Film Policy. November 20, 2006, http://www.obs.coe.int/online-publication/reports/aas.htm

Doğan, Y. (2004, July 20). Silah Bir Sinema İki.Hürriyet Gazetesi,13

Doğan, D.Ç. (2010). " Sinemanın Toplum Hayatındaki Rolü ve Denetimi" Hukuk Gündemi Dergisi, Sayı:2

Erkılıç, H. (2008). " Sinema Politikaları Çerçevesinde Filmlere Sağlanan Devlet Desteği" İstanbul Üniversitesi İletişim Fakültesi Dergisi, Vol.33 No. 1

Hızlan, D. (2005, August 12). Sinemacılara İpotek Baskısı.Hürriyet Gazetesi, 21.

Kıvanç, A. (2004, July 16). Sinema Yasası Çıktı Tartışmalar Sürecek. Radikal Gazetesi, 19.

Özonur, D.Ç. (2010). Avrupa Birliği Uyum Yasaları Çerçevesinde Film Denetleme Sisteminde Yapılan Değişiklikler. http://defnecoloğlu.com/wordpress/?p:70

Ulusoy, N. (2003). Avrupa Merkezli Görsel İşitsel Kuruluşlar ve Türk Sineması. Mine Gencel Bek (Edited by), Avrupa Birliği ve Türkiye'de İletişim Politikaları. Ankara, Ümit Yayıncılık. 